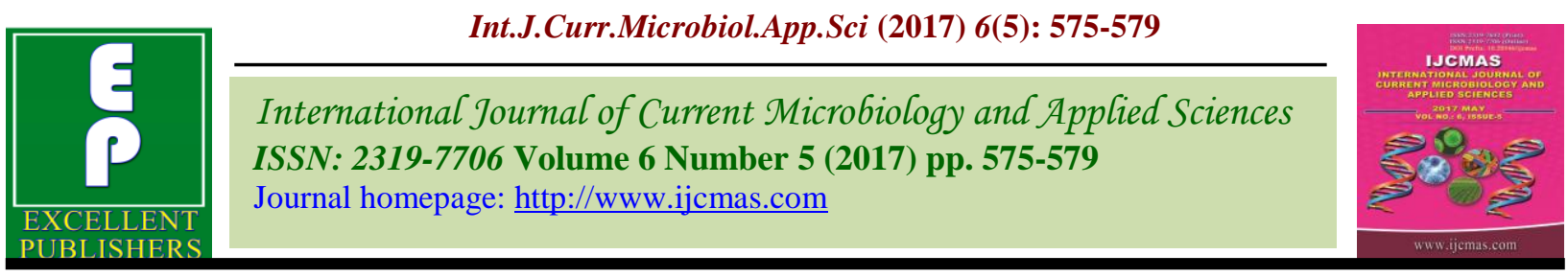

Original Research Article

https://doi.org/10.20546/ijcmas.2017.605.066

\title{
In-vitro Evaluation of Arabidopsis thaliana Ecotypes against Ralstonia solanacearum Race4
}

\author{
Devendra Kumar Choudhary ${ }^{1 *}$, Aundy Kumar $^{1}$ and Sajadun Nabi ${ }^{2}$ \\ ${ }^{1}$ Division of Plant Pathology, ICAR-Indian Agricultural Research Institute, \\ New Delhi 110012, India \\ ${ }^{2}$ ICAR-Central Institute of Temperate Horticulture, Rangreth, Srinagar 190 007, India \\ *Corresponding author
}

\begin{tabular}{|c|c|}
\hline & A B S T R A C T \\
\hline $\begin{array}{l}\text { K e y w o r d s } \\
\text { R. solanacearum, } \\
\text { race } 4 \text {, Arabidopsis } \\
\text { thaliana, } \\
\text { ecotype, wilting, } \\
\text { Resistant. }\end{array}$ & \multirow{3}{*}{$\begin{array}{l}\text { Bacterial wilt caused by the soil-borne bacterium } R \text {. solanacearum race } 4 \text { is a lethal } \\
\text { disease of several vegetables and spices in the family Solanaceae and Zingiberaceae } \\
\text { respectively. In order to understand the phenotypic response of six A. thaliana } \\
\text { ecotypes [Landsberg Erecta (Ler) Columbia- } 0 \text { (Col-0), ABH1, Hc160, Sc1 and SIC] to } \\
R \text {. solanacearum isolate, CaRs-Mep, different dilution of bacterial suspension were } \\
\text { inoculated on roots of plants. The bacterium typically wilted the plantlets in a density } \\
\text { dependent manner where the yellowing and witling was observed within } 7 \text { days and } \\
14 \text { days at } 10 \text { and } 1 \text { OD unit respectively. All ecotypes were highly susceptible to race } \\
4 \text { strain of } R \text {. solanacearum, except ecotype Ler, where no yellowing and changes in } \\
\text { root and shoot length was observed. Ler ecotype showed complete resistant phenotype } \\
\text { and hence can be used in resistance programme against the } R \text {. solanacearum Race } 4 \text {. }\end{array}$} \\
\hline Article Info & \\
\hline $\begin{array}{l}\text { Accepted: } \\
\text { 04 April } 2017 \\
\text { Available Online: } \\
\text { 10 May } 2017\end{array}$ & \\
\hline
\end{tabular}

\section{Introduction}

Bacterial wilt disease caused by Ralastonia solanacearum (Smith, 1896; Yabuuchi et al., 1995) is one of the most important constraints in production of vegetables in the tropical and sub-tropical regions. The bacterial pathogen belonging to $\beta$ Proteobacteria is aerobic non-spore forming, Gram-negative, soil borne, motile with a polar flagellar tuft and has broad host range in over 50 plant family with more than 400 reported host plants (Hayward, 2000). The high incidence of plant mortality and lack of effective control methods make $R$. solanacearum as one of the world's most destructive plant pathogens (Prior et al., 1998). The bacterial species are highly complex with five races, equal number of biovars and four phylotypes. The species divided into 5 different races (race 1-5) based on host range, five biovars (biovar 15) based on carbon utilization/oxidation and four phylotypes (phylotype 1-4) based on conserved nucleotide sequences in the intergenic regions of ribosomal DNA. In India, the predominant races responsible for crop loss are race 1 and race 4 with limited occurrence of race 3 . While race 1 affects solanaceous vegetables, the race 4 is known to infect several plants in the family Zingiberaceae. Race 4 strains of $R$. solanacearum is known to cause wilting in Zingiberaceae plants such as edible ginger in 
many small and marginal farming communities in India and other South East Asian countries who depends on this crop for their livelihood (Sarma and Kumar, 2004). In India, the disease is found in Kerala, Karnataka, Himachal Pradesh, Sikkim, West Bengal, Assam and other North Eastern states. Occurrence of highly aggressive, genetically identical and single virulent lineage of race 4 is found to cause severe wilt in India (Kumar et al., 2014). An integrative approach, which incorporates several methods of control, has been recognized as most successful in curbing disease incidence. Progress towards producing resistant or tolerant plant varieties has been accelerated by the availability of genomic tools in particular, the adoption of A. thaliana as a model plant. Various plant pathogens are also virulent on Arabidopsis, providing a model to conduct pathogenicity tests (Naidoo, 2008). Many ecotype of Arabidopsis are available that shows different phenotype against same pathogen because of the presence or absence of different resistance gene. To better understand the behaviour of $R$. solanacearum race4 / biovar3, we used six different ecotypes of $A$. thaliana in order to evaluate and understand the behaviour of the model plant to race 4 strain of $R$. solanacearum.

\section{Materials and Methods}

\section{Bacterial strain}

The bacterium $R$. solanacearum Race 4/ Biovar 3 strain CaRs-Mep isolated from bacterial wilt affected small cardamom plants. The milky bacterial ooze, so obtained, was streaked onto CPG agar amended with 2, 3, 5triphenyltetrazolium chloride $\left(50 \mu \mathrm{g} \mathrm{ml}^{-1}\right)$ and incubated at $28^{\circ} \mathrm{C}$ for two to three days. Strain resistant to rifamycin at $50 \mu \mathrm{g} \mathrm{ml}^{-1}$ was used in the experiment.

Table.1 Effect of root inoculated $R$. solanacearum race 4 on growth of Arabidopsis ecotypes

\begin{tabular}{|c|c|c|c|c|}
\hline Ecotype & $\begin{array}{l}\text { Root } \\
\text { length } \\
(\mathrm{cm})\end{array}$ & Number of roots & $\begin{array}{l}\text { Shoot Length } \\
\text { (cm) }\end{array}$ & $\begin{array}{l}\text { Number of } \\
\text { Leaf }\end{array}$ \\
\hline Col-0 & 4.26 & 9 & 2.10 & 7 \\
\hline Mock & 4.86 & 9 & 2.71 & 7 \\
\hline Ler & 4.56 & 14 & 2.4 & 9 \\
\hline Mock & 4.65 & 13 & 2.5 & 9 \\
\hline ABH & 1.75 & 3 & 1.57 & 6 \\
\hline Mock & 2.02 & 4 & 1.8 & 6 \\
\hline SIC1 & 1.8 & 4 & 1.3 & 6 \\
\hline Mock & 2.2 & 5 & 1.5 & 6 \\
\hline Sc1 & .8 & 3 & 1.2 & 6 \\
\hline Mock & 1.2 & 4 & 1.5 & 6 \\
\hline Hc160 & 1.6 & 4 & 1.3 & 7 \\
\hline Mock & 2.1 & 6 & 1.7 & 7 \\
\hline
\end{tabular}

@ Bacterial dilution 10 9 cfu/ml 
Fig.1 Phenotypic changes in other ecotypes of Arabidopsis due to colonization by $R$. solanacearum
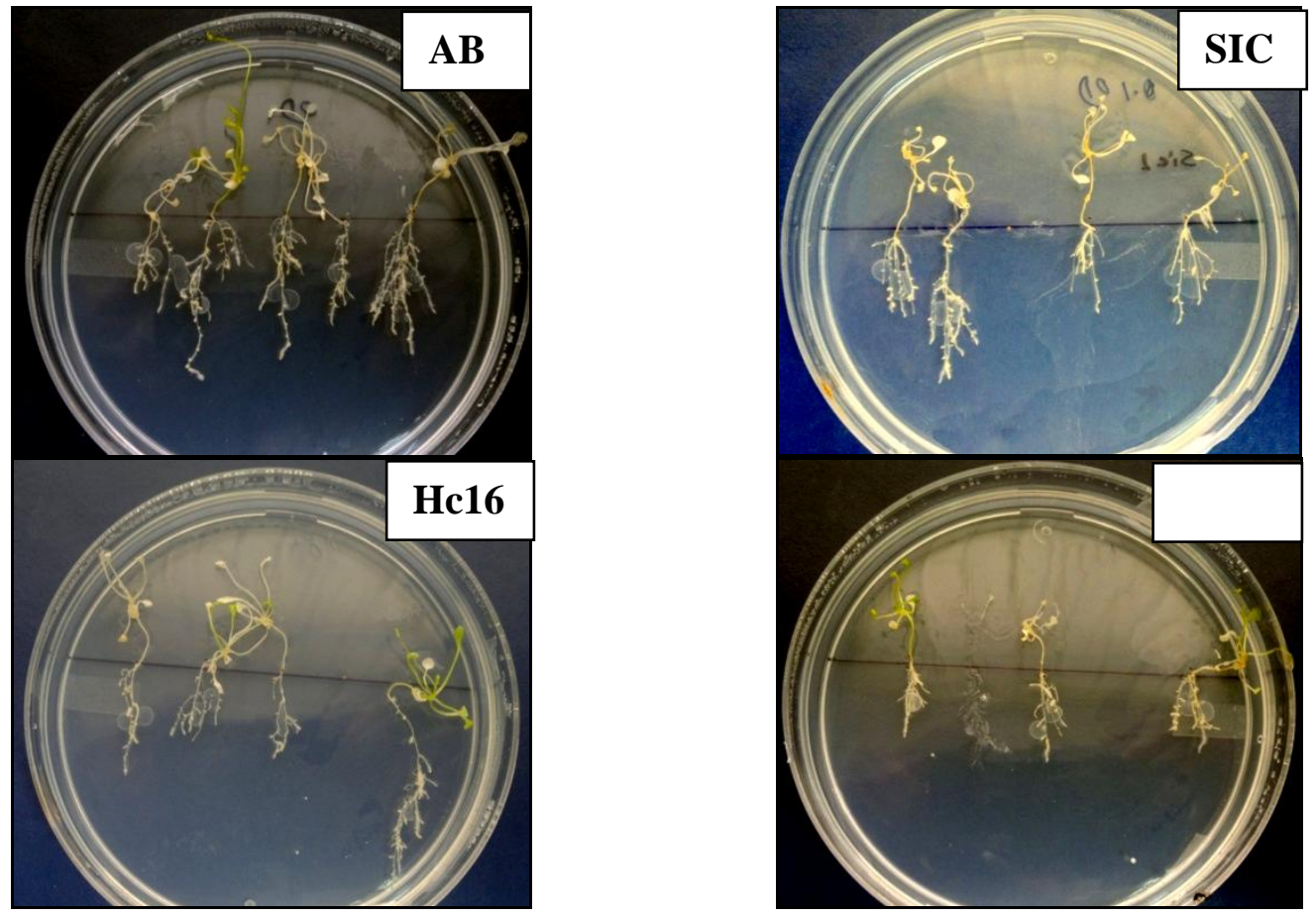

Fig.2 Neither of phenotypic changes in Ler ecotype of Arabidopsis is present

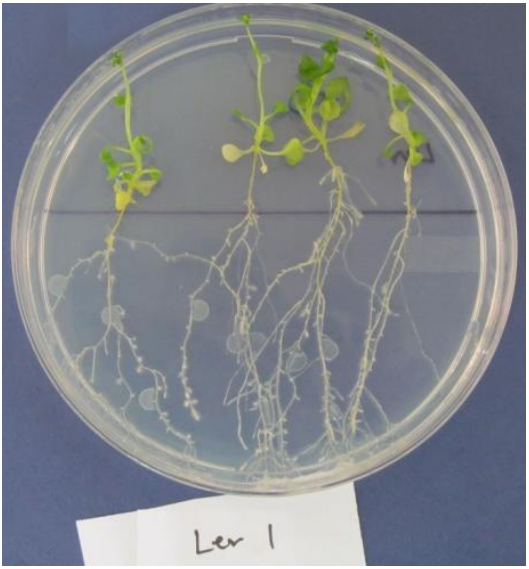

Plant Material and growth condition

Six ecotypes of $A$. thaliana namely; Landsberg Erecta (Ler) and Columbia-0 (Col0), ABH1, Hc160, Sc1 and SIC were used for experimental study. Sterilization of $A$. thaliana seeds was performed by using protocol of Sauer \& Burroughs 1986. Sterilized seeds were placed on Murashige

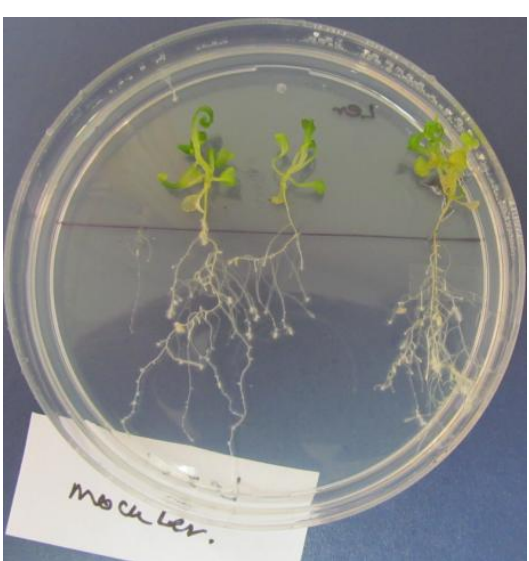

and Skoog medium and different dilution of bacterial suspension ( $5 \mu 1$ per seed) were spot inoculated on seed and on roots of 21 days old plantlets. The seeds were arranged in line at two third of petri plate and transferred to growth chamber, after 48 hours of cold treatment at $4{ }^{\circ} \mathrm{C}$. The Growth conditions were $22 / 20^{\circ} \mathrm{C}$ (day/night) temperature, 24 hours light period and $40 \%$ relative humidity. 


\section{Inoculum preparation and Inoculation}

Ralstonia solanacearum race 4 biovar 3 (CaRs-Mep) were cultured on CPG agar supplemented with rifamycin antibiotic incubated for 72 hours at $28^{8} \mathrm{C} .10^{9}$ and $10^{10}$ $\mathrm{cfu} / \mathrm{ml}$ bacterial suspensions were prepared by using serial dilution method. Fourteen days old plants were taken for inoculation and middle of the root was inoculated with $5 \mu 1$ of bacterial suspension per plants. Separate MS plates were used for varying concentration of bacteria.

\section{Results and Discussion}

During our study Arabidopsis indicated that five ecotypes screened were susceptible to Ralstonia solanacearum race 4 and showed a varying degree of infection percentage. The pathogen attacks primarily on the roots. The severity of symptoms was depended on concentration of bacteria inoculated on roots. Different types of symptoms were observed in five susceptible ecotypes; symptom like yellowing, decay, reduced numbers of roots. $R$. solanacearum-inoculated plants had no symptoms by 2 dpi (Days post inoculation), then started to wilt at 3 or $4 \mathrm{dpi}$ and had wilted completely by 7 dpi (Fig 1). Interestingly, Ler ecotype doesn't showed any changes in phenotype for all tested concentrations and even no wilting symptoms were observed at $30 \mathrm{dpi}$ with $10^{9} \mathrm{cfu} / \mathrm{ml}$ of bacterial suspensions, so we again inoculated the higher dose of bacterial suspension that was $10^{10} \mathrm{cfu} / \mathrm{ml}$, but plants showed no wilting symptoms (Fig 2) indicating that, it is resistant to bacterium $R$. solanacearum. The effect of root inoculated $R$. solanacearum race 4 on growth of Arabidopsis ecotypes is shown in Table 1. In earlier reports, Race 1 strains of the bacterium were used and induced changes have been documented in Arabidopsis (Hu et al., 2008). There are no reports on $A$. thaliana- $R$. solanacearum race 4 interaction published or available still. Landsberg erecta ecoptype showed completely resistant phenotype as no yellowing was observed and also no changes in root and shoot length colonization irrespective of bacterial concentration as indicated by normal growth behavior of the plantlets even after prolonged incubation. Being an important race for India and other ginger growing regions, it becomes essential to find the resistance source against the race. Hence Ler Ecotype can be used in breeding programmes to engineer durable resistance against bacterial wilt pathogen Ralstonia solanacearum Race 4 as there are no reports of resistance source against the bacterial pathogen.

\section{References}

Hayward, A.C. 2000. Ralstonia solanacearum. In: Lederberg, J. Ed.), Encyclopedia of Microbiol., Academic Press, 4: Pp. 32-42.

Hu, J., Barlet, X., Deslandes, L.,Hirsch, J., Feng, D.X., Somssich, I. and Marco.Y. 2008. Transcriptional responses of Arabidopsis thaliana during wilt disease caused by the soil-borne phytopathogenic bacterium, Ralstonia solanacearum. PLOS One, 2: e2589. doi: 10.1371/journal. pone. 0002589.

Kumar, A., Prameela, T.P., Suseelabhai, R., Siljo, A., Anandaraj, M. \& Vinatzer, B.A. 2014. Host specificity and genetic diversity of race 4 strains of Ralstonia solanacearum. Plant Pathol., DOI: 10.1111/ppa.12189.

Naidoo, S. 2008. Microarray expression studies in the model plant Arabidopsis thaliana infected with the bacterial pathogen Ralstonia solanacearum. $\mathrm{PhD}$ thesis. University of Pretoria: South Africa.

Prior, P., Allen, C. \& Elphinstone, J. 1998. Bacterial wilt disease: molecular and ecological aspects, Ed Springer Verlag, Berlin, Germany. 
Sarma, Y.R. \& Kumar, A. 2004. Characterization of Ralstonia solanacearum causing bacterial wilt in ginger. Indian Phytopathol., 57: 12-17.

Smith, E.F. 1896. A bacterial disease of the tomato, eggplant and Irish potato (Bacillus solanacearum nov. sp. Div.
Veg. Phys. Path. Bull.,12. U. S. Dept. Agr., 1896: 1.

Yabuuchi, E., Kosako, Y., Yano, I., Hotta, H. \& Nishiuchi, Y. 1995. Transfer of Two Burkholderia and An Alcaligenes Species to Ralstonia Gen. Nov. Microbiol. Immunol., 39: 897-904.

\section{How to cite this article:}

Devendra Kumar Choudhary, Aundy Kumar and Sajadun Nabi. 2017. In-vitro Evaluation of Arabidopsis thaliana Ecotypes against Ralstonia solanacearum Race4. Int.J.Curr.Microbiol.App.Sci. 6(5): 575-579. doi: https://doi.org/10.20546/ijcmas.2017.605.066 